\title{
CS Research Square

\section{Parasporin A13-2 of Bacillus thuringiensis isolate from Papaloapan region, induce a cytotoxic effect by late apoptosis against breast cancer cells}

Diego Becker Borin

Universidad del Papaloapan

Karen Castrejón-Arroyo

Universidad del Papaloapan

Alain Cruz-Nolasco

Universidad del Papaloapan

Miguel Angel Peña-Rico

Universidad del Papaloapan

Michelle Sagrillo Rorato

Franciscan University

Roberto C.V. Santos

Universidade Federal de Santa Maria

Lucas Silva de Baco

Franciscan University

Lemuel Pérez-Picaso

Universidad del Papaloapan

Luz Camacho

Instituto Nacional de Pediatría

Ana K. Navarro-Mtz ( $\square$ anavarro@unpa.edu.mx )

Universidad del Papaloapan

\section{Research Article}

Keywords: protein A13-2, Bacillus thuringiensis, Papaloapan watershed, breast cancer cell, MCF- 7

Posted Date: March 17th, 2021

DOl: https://doi.org/10.21203/rs.3.rs-283985/v1

License: (c) (i) This work is licensed under a Creative Commons Attribution 4.0 International License.

Read Full License 
Parasporin A13-2 of Bacillus thuringiensis isolate from Papaloapan region, induce a cytotoxic effect by late apoptosis against breast cancer cells

Becker Borin, D. ${ }^{\mathrm{a}}$, Castrejón-Arroyo, K. ${ }^{\mathrm{b}}$, Cruz-Nolasco, A. ${ }^{\mathrm{c}}$, Peña-Rico, M.A. ${ }^{\mathrm{a}}$, Sagrillo Rorato, M. ${ }^{\mathrm{d}}$, Santos, R.C.V. ${ }^{\mathrm{e}}$, Silva de Baco, L., Pérez-Picaso, L., , Camacho L. ${ }^{\mathrm{h}}$, Navarro-Mtz, A.K. ${ }^{\mathrm{a}^{*}}$.

${ }^{a}$ Instituto de Biotecnología, Universidad del Papaloapan, Tuxtepec, Oaxaca, México.

bDivisión de Estudios de Posgrado, Maestría en Biotecnología, Universidad del Papaloapan, Tuxtepec, Oaxaca, México.

'División de Estudios de Posgrado, Doctorado en Biotecnología, Universidad del Papaloapan, Tuxtepec, Oaxaca, México.

${ }^{\mathrm{d}}$ Graduate Program in Nanoscience, Franciscan University, Santa Maria, Rio Grande do Sul, Brazil.

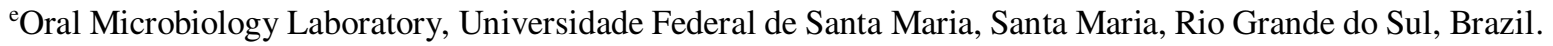

${ }^{\mathrm{f} O n c o l o g i a, ~ F r a n c i s c a n ~ U n i v e r s i t y, ~ S a n t a ~ M a r i a, ~ R i o ~ G r a n d e ~ d o ~ S u l, ~ B r a z i l . ~}$

Instituto de Química Aplicada, Universidad del Papaloapan, Tuxtepec, Oaxaca, México.

hLaboratorio de Nutrición Experimental, Instituto Nacional de Pediatría, Ciudad de México, México.

*Email address: anavarro@unpa.edu.mx; Telephone: (+52) 2878759240 ext.220; Fax: (+52) 2878759240 ext.230 (A.K. Navarro-Mtz).

ORCID Castrejón-Arroyo 0000-0002-9035-3007; Peña-Rico 0000-0001-8275-6044; Sagrillo Rorato 00000001-5659-159X; Santos RCV 0000-0002-0533-3483; Silva de Baco 0000-0003-0213-7353; Pérez-Picaso, L 0000-0002-1957-3349; Camacho L 0000-0002-9864-3738; Navarro-Mtz 0000-0003-4124-5533. 


\begin{abstract}
The protein A13-2 was obtained from Bacillus thuringiensis strains isolated from the Papaloapan watershed region (Oaxaca, Mexico). The cytotoxic activity of parasporal inclusions was studied against breast cancer cell line (MCF-7) and normal cell (human peripheral blood mononuclear cells). The MTT, the formation of reactive species, nitric oxide, free cell DNA, and the type of death cellular were assessed. The protein A13-2 shows the highest cytotoxic activity against MCF-7 (13\% at $6 \mu \mathrm{g} / \mathrm{mL})$, the extracellular DNA increases, and it shows no stress for reactive species or nitric oxide. Besides, the A13-2 parasporin shows no toxicity to peripheral blood mononuclear cells, and it does not generate changes in nitric oxide levels or free cell DNA. According to microscopy and flow cytometry, A13-2 leads to the death of MCF-7 cell by late apoptosis. Due to that, the cytotoxic effect of A13-2 was specific for MCF-7, and it does not affect peripheral blood mononuclear cells (normal cells). When analyzed together, our results show for the first time that the A13-2 protein isolated from Mexican strains of $B$. thuringiensis has a high selectivity against the MCF- 7 cell line, thus representing a promising alternative for the treatment of cancer breast.
\end{abstract}

\title{
Introduction
}

Bacillus thuringiensis is a Gram-positive bacterium that during the sporulation stage produces parasporal crystals [1]. The parasporal crystals can be constituted of the proteins Cry, Cyt, and parasporins, each of them with particular activities, insecticidal, hemolytic and anticancer respectively [2,3]. Parasporins are a set of proteins that are divided or grouped into six families (PS1-PS6) and they have different sizes and modes of action [4]. It has been demonstrated that parasporins are cytotoxic against mammalian cancer cells [5-8]. The molecular weights of proteins are from 34 to $94 \mathrm{kDa}$. Most of $B$. thuringiensis parasporins are from strains isolated from the Asian continent (Japan, Vietnam, Malaysia, and India) [9]. Although, there are reports of this type of strain in America, in the Caribbean islands, Canada and México $[9,10]$.

The parasporins are good candidates for cancer therapy due to their selective activity against cancer cells and their ubiquity [11]. Breast cancer is the second most prevalent in the world and leads to 627,000 deaths per year [12]. It is considered the most common malignancy in women; whose treatment methods depend on molecular subtype and the stage of breast cancer. The main treatments are surgery, chemotherapy, and hormonal therapies. The principal disadvantage about these treatments is its poor specificity for cancer cells because they attack or released factors that can damage the DNA of normal cells, affecting even more so the patient and causing collateral and irreversible damage in some cases [13]. The scientific community remains in the constant struggle to generate new strategies to avoid these side effects. i.e., the creation of drugs that directly attack cancer cells without damaging other tissues implying a lower risk of negative effects and improving the quality of life of the affected people. Even though, the parasporin definition is: "Bacillus thuringiensis and related bacterial parasporal proteins that are non-hemolytic but capable of preferentially killing cancer cells" [4], a few reports 
are found in the literature about the effect of the parasporins against normal cells. Therefore, the aim of this study was to obtain a new parasporin produced by $B$. thuringiensis with high selectivity: activity against breast cancer and without toxicity against normal cells.

\section{Results}

\section{Selection of strains and proteins}

The SDS-PAGE gels for protein purification process show that A-13 strain produced bands of approximately 26 and $30 \mathrm{kDa}$ (fig. 1). The bands for cytotoxicity assay were selected according to their size and intensity; and they were called A13-2 (26 kDa) and A13-5 (30 kDa) (fig. 1).

Fig. 1

\section{Cytotoxic effect of parasporal protein A13-2 in MCF-7 7 and PBMC cells}

The cytotoxic activity assay results of the MCF-7 cells treated with the parasporal protein A13-2 during $48 \mathrm{~h}$ are shown in figure 2a. Data show that the A13-2 protein is cytotoxic against MCF-7, at $6 \mu \mathrm{g} / \mathrm{mL}$ cell viability has been reduced by $87 \%$, while A13-5 protein at $8 \mu \mathrm{g} / \mathrm{mL}$ reduces cell viability by $80 \%$. These results indicate that MCF-7 cells are more susceptible to A13-2 protein than normal PBMC cells. Therefore, A13-2 protein was chosen for further analysis.

\section{Fig. 2}

Interestingly, MTT assays in PBMC (normal cells) at 48 hours incubation using the A13-2 and A13-5 treatments show no cytotoxic effect at the concentrations tested (fig. 2b), suggesting high selectivity of these parasporal proteins against cancerous cells. While the cells treated with A13-5 showed no significant difference with the control.

\section{Role of oxidative stress in the cytotoxicity of A13-2 protein in MCF-7 and PBMC cells}

In figures $3 \mathrm{a}$ and $3 \mathrm{~b}$ are shown the results for NO assay of the parasporal protein against MCF-7 and PBMC, respectively. The parasporal protein treatments increase the NO levels to $24 \%$ at $4 \mu \mathrm{g} / \mathrm{mL}$ in MCF-7 cultures. That increment is not enough to trigger the oxidative stress. There are no significant differences in NO levels for parasporal protein treatments against PBMC cells.

\section{Fig. 3}


On the other hand, the levels of Reactive Oxygen Species (ROS) after parasporal protein A13-2 treatments were not significantly different after $48 \mathrm{~h}$ in MCF-7 (fig. 3c); while in PBMC, a significant reduction in ROS levels were observed at concentrations of 4 and $8 \mu \mathrm{g} / \mathrm{mL}$ (fig. 3d).

\section{Morphological changes and cell death mechanism induced by parasporal protein A13-2}

Morphological changes are associated with damage in the cells; thus, a microscopy analysis of MCF-7 cells with parasporal protein A13-2 treatment was performed (Fig. 4). The cytopathic effect results are shown in fig. 4c-4f. No detectable cytopathy was induced by A13-2 protein in the control group (fig 4c). The cells show a normal angular or polygonal shape, while the cytopathy induced by the parasporal protein A13-2 an exhibited typical irregular morphology of cells in apoptotic processes on MCF-7 cells at $48 \mathrm{~h}$ of incubation (fig. $4 \mathrm{e}$ and 4f). The cells show as a round or oval dark mass associate to nuclear chromatin fragments, the morphology is almost normal polygonal shape with marked lesions that appear on the surface of the plasma membrane indicating a late stage of apoptosis cell death (fig 4e and 4f). As expected, doxorubicin evidence signs of apoptosis as the cytoplasm and chromatin condensation and the formation of apoptotic bodies (fig 4d).

The apoptotic morphology of MCF-7 treated with A13-2 is confirmed with the cytometry test (fig. 4b). Annexin $\mathrm{V}$ and propidium iodide were used to determine if death was caused by necrosis or apoptosis. Most events are restricted to quadrant R5 in control cells i.e., viable cells (fig. 4a). Cells treated with protein A13-2 have a large number of events in quadrant R4 and R3 representing late apoptosis and necrosis, respectively, (fig. 4b), wich suggests that parasporal protein A13-2 induce high toxicity on MCF-7 cells. This result agrees with the MTT, NO, ROS and Picogreen test results.

\section{Fig. 4}

\section{Discussion}

B. thuringiensis may produce different parasporins with different molecular weights and levels of cytotoxicity to diverse cancer cell lines. Nair et al. [14] analyzed 18 isolated strains of B. thuringiensis cultivated in T3 agar plates, incubated at $30^{\circ} \mathrm{C}$ for $96 \mathrm{~h}$, observing that at least six different parasporal proteins were produced by each isolated in different sizes and concentration. Brasseur et al. [15] reported that B. thuringiensis 4R2, cultivated at $30^{\circ} \mathrm{C}$ on nutrient agar at $\mathrm{pH} 7.1$, produces five parasporal proteins where the one at $37 \mathrm{kDa}$ was identified as PS2Aa1. This variation in the number of parasporal proteins found is due to the growth and environmental conditions of each B. thuringiensis strain. In soil, the bacteria population is not randomly distributed because factors such as soil composition, organic matter, $\mathrm{pH}$, water availability and oxygen, along with the host plant, play an essential role in the adaptation of this microflora [16]. 
The cytotoxicity effect of A13-2 and A13-5 (26 and $30 \mathrm{kDa}$, respectively) on MCF-7 cells was similar to that described in previous reports. Brasseur et al. [15] reported that PS2Aa1 (37 kDa) had good activity against MCF-7 at of $2.5 \mu \mathrm{g} / \mathrm{mL}$ reducing viability to $20 \%$. However, the authors used chemical or enzymatic processes for protein activation. Maher [17] identified two strains J61 and J72 with cytotoxic activity against MCF-7 that reduce to $50 \%$ cell viability at $1 \mu \mathrm{g} / \mathrm{mL}$ and $2.79 \mu \mathrm{g} / \mathrm{mL}$, respectively. Other authors tested differents parasporins observing no significant cytotoxic activity against MCF-7 [18-20]. It has been reported that a parasporin could affect more than one cancer line cells. Brasseur et al. [15] and Maher [17] demonstrated that their parasporins also showed cytotoxicity against other cancer cells such as MDA-MB231, PC-3, HepG2, CACO-2, K562 and Hep2.

Interestingly, MTT assays in PBMC (normal cells) at 48 hours incubation using the A13-2 and A13-5 treatments show no cytotoxic effect at the concentrations tested (fig. 2b), suggesting high selectivity of these parasporal proteins against cancerous cells. While the cells treated with A13-5 showed no significant difference with the control. Just in a few studies have been detected low or no activity in MTT assays of parasporin against normal immune cells $[18,21,22]$.

To mechanistically understand how parasporal proteins A13-2 reduces cell proliferation and to identify if oxidative stress is involved, NO and ROS levels were examined after exposure to different concentrations of parasporal protein A13-2. Cancer cells have a dual cellular response to oxidative stress. When the stress levels are low, the cells activate essential processes that guarantee their survival; while at high levels of stress, the cells died due to oxidative damage [23]. Moreover, cancer cells are more susceptibles to oxidative stress than normal cells, a small increment in the oxidative environment activates the death mechanisms in cancer cells but not in the normal cells [24].

The role of NO in cancer is complex, it has been reported that it is involved in multiple steps of tumor development, but it is also involved in the cell cycle arrest, i.e., in the apoptosis. [25]. NO can act as an intraand extracellular signaler participating in numerous pathological processes. It is a modulator in several essential biological processes, and it has a dubious role to cells, sometimes beneficial and sometimes harmful [26]. Also, NO is an important cytotoxic mediator of effector cells capable of destroying pathogens and tumor cells [27]. However, NO is potentially toxic, especially in situations of oxidative stress, generation of oxygen intermediates and antioxidant system deficiencies [28]. The nitric oxide synthase (iNOS) is responsible for the endogenous production of NO. iNOS is only expressed when it is induced by cytokines or endotoxins in cells such as macrophages, T lymphocytes, neutrophils, and platelets, among others [29]. Hence, for MCF-7 and PBMC cultures with a parasporal protein treatment, the NO levels measured indicate than the cells were not induced to produce proinflammatory cytokines and that the parasporal proteins were not recognized as endotoxins.

The dichlorofluorescein (DCFH-DA) is the most widely used probe for detecting oxidative stress through measurement of ROS formation due to the increment in $\mathrm{H}_{2} \mathrm{O}_{2}$, due to the changes in intracellular iron signaling 
and due to the peroxynitrite formation [30]. Probably, natural ROS scavengers in MCF-7 and PBMC cells, like the glutathione peroxidase, catalase, and superoxide dismutase, can control the increment in the ROS levels and therefore maintaining it in non-toxic levels. Likewise, the increase in PBMC proliferation observed after the A13-2 treatment might involve signaling mechanisms related to ROS levels. Previous studies described that the presence of low ROS levels in some blood cells induce its proliferation [31,32]. The most chemotherapeutic agents and radiotherapy treatment lead to apoptosis death cells by inducing intracellular ROS production $[33,34]$. Furthermore, it has been proposed that in peptide therapy, one possible mechanism of cell damage is associated with the increment of intracellular ROS [33,34]. Although, the results of the oxidative stress point out that the cytotoxic effect of parasporal protein A13-2 is not through this process.

Due to endogenous and exogenous factors, the DNA could be fragmented, and it could be exported out of the cells. Hence, through the detection of DNA in the medium, a genotoxic effect may be evaluated [35] and also, indirectly the formation of pores in the membrane [36]. Some authors proposed that one of the possible cytotoxic mechanisms of parasporins is through the formation of pores in the membrane of the tumor cells, which leads to an osmotic imbalance and consequently to the cell death [37-39]. The Picogreen assay is an easy and fast technique to detect a minimum amount of dsDNA (25 pg/mL) in the medium [40]. Therefore, DNA in the medium was measured in MCF-7 cells after parasporal protein A13-2 treatment with Picogrenn assay. The results for MCF-7 cells treated with parasporal protein A13-2 show that the increment of the double-stranded DNA (dsDNA) in the medium is a protein concentration-dependent (fig. 3e). The dsDNA fragments release was significant at 8 and $12 \mu \mathrm{g} / \mathrm{mL}$ indicating that MCF-7 cells were damaged, probably due to cellular apoptosis and necrotic cell (fig. 3e). Although, in PBMC cells, this damage was not observed (fig. 3f). Currently, there is no data available in the literature about the ROS and NO levels or even in the fragmented dsDNA concentration in cultures treated with parasporin. However, what is clear is that there is specific membrane damage induced by parasporal protein A13-2 on the breast cancer cells, where the formation of pores in the membrane might be related.

\section{Morphological changes and cell death mechanism induced by parasporal protein A13-2}

The MTT test shows that A13-2 promotes cell death and NO-ROS results show that this protein does not trigger oxidative stress in MCF-7 (fig. 3a-3d). Moreover, the Picogreen test shows fragmented free dsDNA in the medium associated with death by necrosis at $48 \mathrm{~h}$ (fig. 3e). Additionally, cytometry test indicated that at $48 \mathrm{~h}$ with A13-2 most of the cells were death by necrosis, however a small percentage were at late apoptosis suggesting a rapid transition from late apoptosis to necrosis, which could point out that lower concentrations or times-course analysis perhaps will allow us to observe more apoptotic signals. Therefore, A13-2 protein could be interacting with the cell membrane, leading to the formation of pores that drives to cell death.

It has been reported different mechanisms of cell death treated with parasporins. PS1Aa1 against HeLa cells showed a rapid intracellular increment of $\mathrm{Ca}^{2+}$ but without lactate dehydrogenase release and IP internalization, 
which is strong evidence of death by apoptosis [41]. For PS2Aa1 against HepG2, an increment in the membrane permeability was observed where the lactate dehydrogenase extravasation and the PI internalization are due to a similar mechanism to Clostridium perfringens epsilon toxin. PS2Aa1 has homology with epsilon toxin, that is a pore-forming when it is in contact with lipid rafts [42]. PS3Aa1 has closely resembled pore-forming insecticidal Cry proteins, where cancer cells die by increasing membrane permeability [43]. PS4 is nonspecifically bounded to the membrane forming a cholesterol-independent oligomeric pore complex and also shows some homology to $\alpha$-toxin, aerolysin, and $\varepsilon$-toxin [44]. PS5 has no similarity to other parasporins or Cry proteins but exhibits some homology to $\beta$-pore-forming Aerolysins ( $\beta$-TFPs) and to epsilon toxin, that are poreforming toxins [45] There is little information about PS6, although, it is considered as a three-domain Cry protein with $56.4 \%$ identity to Cry2 insecticidal proteins [44]. Thus, all our results show that A13-2 is a parasporin with cytotoxic effect over MCF-7 cells.

\section{Conclusion}

The main disadvantage of the actual therapies for cancer disease is that they are toxic for normal cell generating several side effects and deteriorating the patient's quality of life. The parasporin produced for B. thuringiensis A13-2 is cytotoxic effect in MCF-7 cancer cells and it does not have toxic activity against peripheral blood mononuclear cells (non-cancerous cells), i.e., it is specific for the cancer cell. Also, this parasporin leads to cell death by late apoptosis and without triggering oxidative stress. The fundamental goal of cancer treatments is the identification of molecules with high capacity to induce selective cancer cell death, locking the chance to activate the mechanism of survival of the cancer cells. In this context, late apoptosis induced by parasporal protein A13-2 together with necrosis could be the best death mechanisms both mechanisms are irreversible for cells, it has been reported that cancer cells can progressively develop acquired resistance to apoptotic cell death, thus with parasporal protein A13-2 the death is carried out quickly without allowing the triggering of the survival mechanisms. As parasporin extraction and characterization methods are well established, large-scale production by the pharmaceutical industry is plausible and perfectly executable. Although, further studies regarding the mechanisms of cell death and in vivo effects of these proteins have to be done. Moreover, about the elucidation of protein structure, the pathways of cytotoxicity and non-toxicity towards normal cells could lead, in the future, to the drug design.

\section{Materials and Methods}

\section{Bacterial strains and culture conditions}

B. thuringiensis strains used were isolated from the Papaloapan watershed region [45]. The strains were cultivated in a Gerry-Rowe medium (MCD Lab.) at a pH of 7.4 (adjusted with $40 \% \mathrm{NaOH}$ ) at $180 \mathrm{rpm}$ for 
seven days at $30^{\circ} \mathrm{C}$ (New Brunswick Benchtop Incubator Shaker I24, Eppendorf) to obtain the protein extracts. Once the fermentation was concluded, the culture medium was centrifuged at $5500 \mathrm{rpm}$ for $20 \mathrm{~min}$ at $5{ }^{\circ} \mathrm{C}$ and washed with distilled water, acidified water ( $\mathrm{pH} 2.5$; three times), distilled water, $\mathrm{NaCl} 0.85 \% \mathrm{w} / \mathrm{v}$ (three times) and distilled water, in that order. For every wash, the pellet was resuspended of the solution and centrifuged at $5500 \mathrm{rpm}$ for $20 \mathrm{~min}$ at $5{ }^{\circ} \mathrm{C}$. After washing, the pellet was resuspended in $5 \mathrm{~mL}$ of distilled water [10].

\section{Parasporal inclusion isolation}

For parasporal inclusions isolation, all the washed protein extracts were solubilized with 1:2 of Laemmli buffer at $100{ }^{\circ} \mathrm{C}$ for $5 \mathrm{~min}$ [46]. Then, the protein extracts were separated by molecular weight through sodium dodecyl sulfate polyacrylamide gel electrophoresis (SDS-PAGE) at 12\%, with bovine serum albumin (BSA) as a reference protein. The molecular masses of proteins were estimated by molecular mass standards $(170,130,95$, $72,55,43,34,26,17$, and $10 \mathrm{kDa}$, ThermoScientific). The interest bands (32 to $26 \mathrm{kDa}$ ) were cut from the gel and recovered by electroelution at $10 \mathrm{~mA}$ for 210 minutes in a Bio-Rad Mini-Protean ${ }^{\circledR}$. The eluted proteins were dialyzed using bioseparation columns (Ultrafree-MC for volumes less than $0.5 \mathrm{~mL}$ with a pore size of $6,000 \mathrm{Da}$ ) to remove the SDS reagent and obtain parasporal inclusions-SDS free. Washes were carried out with phosphate buffer (PBS), at 13,300 rpm, 10 minutes at $4{ }^{\circ} \mathrm{C}$. Protein quantification was done in a NanoDrop 2000/2000c using the Protein A280 method.

\section{Cell culture conditions}

\section{PBMC culture conditions}

Peripheral blood mononuclear cells (PBMCs; non-cancerous cells) were donated from the Clinical Analysis Laboratory of the Franciscan University (LEAC-UFN). The LEAC-UFN laboratory obtained the cells from blood samples discarded from healthy adults (experimental protocols used were approved by the UFN Ethics Committee on Human Beings; CAAE número: 31211214.4.0000.5306) with absence of identification data. PBMC was maintained in Roswell Park Memorial Institute Medium (RPMI 1640 Biowest) at pH 7.4, supplemented with $10 \%$ fetal bovine serum (Biowest), $100 \mathrm{U} / \mathrm{mL}$ penicillin, $100 \mu \mathrm{g} / \mathrm{mL}$ streptomycin (Biowest), and $2 \mathrm{mM} \mathrm{L}$-glutamine (Biowest). The PBMC were maintained at $37{ }^{\circ} \mathrm{C}$ with saturated humidity and $5 \% \mathrm{CO}_{2}$. All procedures performed were in accordance with the ethical standards of the institutional and/or national research committee and with the 1964 Helsinki declaration. According to the UFN Ethics Committee on Human Beings signed informed consent were no needed. 


\section{MCF-7 cells culture conditions}

The human breast cancer cell line MCF-7 was acquired from American Type Culture Collection (ATCC®) HTB-22 ${ }^{\text {TM }}$, Manassas, VA, USA). MCF-7 was at passage 12 when it was used in study and routinely cultured on monolayers at 80\% confluence in Dulbecco's modified Eagle's High glucose medium (DMEM, Biowest), supplemented with $10 \%$ fetal bovine serum (Biowest), $100 \mathrm{U} / \mathrm{mL}$ penicillin, $100 \mu \mathrm{g} / \mathrm{mL}$ streptomycin (Biowest), and $2 \mathrm{mM} \mathrm{L}$-glutamine (Biowest). All cells were maintained at $37{ }^{\circ} \mathrm{C}$ with saturated humidity and $5 \% \mathrm{CO}_{2}$. To harvest MCF-7 cells, the growth medium was removed and cells were washed with phosphate buffer saline (PBS, Biowest). To produce a cellular suspension, a cell dissociation solution made of trypsinEDTA (Biowest) was added and incubated at $37{ }^{\circ} \mathrm{C}$ for $3 \mathrm{~min}$ in a humidified $5 \% \mathrm{CO}_{2}$ incubator. Trypsinized cells were reseeded in fresh medium at $10^{5}$ cells $/ \mathrm{ml}$ and incubated at $37{ }^{\circ} \mathrm{C}$ in a humidified $5 \% \mathrm{CO}_{2}$ incubator.

\section{Cytotoxicity assays}

The cytotoxicity of parasporal inclusions was evaluated by 3-(4,5-Dimethylthiazol-2-yl)-2,5 diphenyltetrazolium bromide (MTT) assay [47]. MCF-7 and PBMC cells (2500 cell/20 $\mu \mathrm{L})$ were cultured in 96-well microplates with RPMI 1640 medium and DMEM high glucose, respectively, and incubated at 5\% $\mathrm{CO}_{2}$ for 24,48 , or $72 \mathrm{~h}$ with 4 to $16 \mu \mathrm{g} / \mathrm{mL}$ of protein. After incubation, $20 \mu \mathrm{L}$ of MTT ( $5 \mathrm{mg} / \mathrm{mL}$ ) dissolved in PBS were added and incubated for $4 \mathrm{~h}$. At the end of this time, the medium was removed and the insoluble formazan crystals were dissolved with $200 \mu \mathrm{L}$ of dimethylsulfoxide (DMSO). The optical density produced by this product was read at a wavelength of $595 \mathrm{~nm}$ using a microplate reader (Bio-Rad iMark). Each treatment was performed by triplicate and repeated three times using $200 \mu \mathrm{L}$ of DMEM as a negative control (NC).

\section{Nitric Oxide test}

Nitric Oxide (NO) production was evaluated as metabolite involved in the apoptosis induction for MCF-7 and PBMC cells [48,48]. After 72 and $48 \mathrm{~h}$ incubation of MCF-7 and PBMC, respectively, with the parasporal protein treatments, the culture plate was centrifuged $10 \mathrm{~min}$ at $2000 \mathrm{rpm}$. In a new plate, $50 \mu \mathrm{L}$ of the supernatant and $50 \mu \mathrm{L}$ of the Griess reagent (1\% Sulfanilamide and $N$-1-naphthylethylenediamine-bicyclic $0.1 \%$ ) were added. The plate was incubated for 15 minutes at room temperature. Subsequently, the absorbance produced was read in a TP-Reader plate reader (Thermoplate, China) at $570 \mathrm{~nm}[50,51] .200 \mu \mathrm{L}$ of DMEM was used as a negative control (NC). The data were expressed as a percentage of free $\mathrm{NO}$ in the medium concerning the negative control: with \% NO free in the middle $=($ Absorbance of the sample $* 100) /$ average of the negative control. 


\section{Reactive oxygen species assay}

The dichlorofluorescein (DCFH-DA) was used to indirectly measure the total rate of reactive oxygen species (ROS) present. After 72 and $48 \mathrm{~h}$ incubation of MCF-7 and PBMC, respectively, with the parasporal treatments, the culture plate was centrifuged for $10 \mathrm{~min}$ at $2000 \mathrm{rpm}$, and in a dark new plate was added $100 \mu \mathrm{L}$ of supernatant, $130 \mu \mathrm{L}$ of Tris- $\mathrm{HCl}(10 \mathrm{mM}, \mathrm{pH} 7.4)$ and $20 \mu \mathrm{L}$ of DCFH-DA (1 mM). $200 \mu \mathrm{L}$ of DMEM was used as a negative control. The plate was incubated for 60 minutes in the dark at room temperature. The reading was made done on a fluorescence meter (SpectraMax ${ }^{\circledR} \mathrm{i} 3 \mathrm{x}$-Molecular devices) at $525 \mathrm{~nm}$ emission wavelength and $488 \mathrm{~nm}$ of excitation [52,53]. The data were expressed as a percentage of the total rate of ROS concerning the negative control with $\%$ Total rate of ROS $=($ Absorbance of the sample $* 100) /$ average of the negative control.

\section{Genotoxicity assay}

The Picogreen test is fluorimetric and quantifies the double strand of DNA by binding to it and emitting fluorescence when it is released into the medium by cellular apoptosis or necrosis. After 72 and $48 \mathrm{~h}$ incubation of MCF-7 and PBMC, respectively, with parasporal protein treatments, the culture plate was centrifuged for 10 minutes at $2000 \mathrm{rpm} .10 \mu \mathrm{L}$ of the supernatant was placed in a new dark plate, homogenized with $80 \mu \mathrm{L}$ of TE buffer and it was added $10 \mu \mathrm{L}$ of the Picogreen reagent diluted in TE buffer (1:200). The reaction was incubated at room temperature and in the darkness for $5 \mathrm{~min}$. The reading was performed on a fluorimeter (SpectraMax ${ }^{\circledR}$ i3x -Molecular devices) at a $520 \mathrm{~nm}$ emission wavelength and $480 \mathrm{~nm}$ of excitation [54], and $200 \mu \mathrm{L}$ of DMEM was used as a negative control. The data were expressed as a percentage of a double strand of free DNA in the medium concerning the negative control with $\%$ Dc of free DNA in the medium $=($ Fluorescence $* 100) /$ mean of the negative control.

\section{Apoptosis detection by Annexin V/PI assay}

FITC Annexin V/Dead Cell Apoptosis Kit (Molecular Probes Inc., Eugene, Oregon, USA) was used according to the manufacturer's instructions. Annexin V binds to phosphatidylserine on the outer leaflet of the plasma membrane, and its presence on the outer leaflet is a unique feature of early apoptosis. Propidium Iodide (PI) binds to DNA from cells with disrupted cell membrane, as in late apoptosis and necrosis, being excluded from cells with intact membrane [55]. Cells incubated $24 \mathrm{~h}$ with parasporal protein were collected, washed with PBS and diluted in 1X Annexin Binding buffer $(100 \mu \mathrm{L})$. For each sample, $5 \mu \mathrm{L}$ of Annexin V and $2 \mu \mathrm{L}$ of PI were added to the cell suspension and incubated for $15 \mathrm{~min}$ at room temperature. An additional $100 \mu \mathrm{L}$ volume of Annexin binding buffer was added to each sample for a total of $200 \mu \mathrm{L}$. Samples were analyzed (5000 events) 
using a BD FACSAria flow cytometer, and the analysis was performed using BD FACSDiva software (Becton, Dickinson and Company, Franklin Lakes, NJ, United States).

\section{Light microscopic observation}

The possible MCF-7 cell morphological changes induced by parasporal protein A13-2 incubated during 24, 48 and $72 \mathrm{~h}$ were analyzed by light microscopy. The cytopathic effect was monitored by an inverted microscope (Motic AE31E, Moticam 5 plus). The images were captured and analyzed for cell morphology with the Motic images plus 3.0 software.

\section{Statistical analysis}

Data were analyzed using a One-Way ANOVA (Analysis of Variance) with Graphpad Prism software version 5.0. The Dunnet test was applied to compare each treatment with the control, with a statistical significance of $\mathrm{p}<0.05$.

\section{References}

[1] Schnepf E, Crickmore N V, Van Rie J, Lereclus D, Baum J, Feitelson J, et al. Bacillus thuringiensis and its pesticidal crystal proteins. Microbiol Mol Biol Rev. Am Soc Microbiol; 1998;62:775-806.

[2] Mizuki E, Ohba M, Akao T, Yamashita S, Saitoh H, Park YS. Unique activity associated with noninsecticidal Bacillus thuringiensis parasporal inclusions: In vitro cell-killing action on human cancer cells. J Appl Microbiol. 1999;86:477-86.

[3] Hu Y, Georghiou SB, Kelleher AJ, Aroian RV. Bacillus thuringiensis Cry5B Protein Is Highly Efficacious as a Single-Dose Therapy against an Intestinal Roundworm Infection in Mice. Keiser J, editor. PLoS Negl Trop Dis [Internet]. Public Library of Science; 2010 [citado el 15 de diciembre de 2019];4:e614. Recuperado a partir de: https://dx.plos.org/10.1371/journal.pntd.0000614

[4] Okumura S, Ohba M, Mizuki E, Crickmore N, Côté JC, Nagamatsu Y, et al. Parasporin nomenclature. 2011 9 18)[2002 06 12]. http//parasporin. fitc. pref. fukuoka. jp. 2010.

[5] Ito A, Sasaguri Y, Kitada S, Kusaka Y, Kuwano K, Masutomi K, et al. A Bacillus thuringiensis crystal protein with selective cytocidal action to human cells. J Biol Chem. ASBMB; 2004;279:21282-6.

[6] Okumura S, Saitoh H, Ishikawa T, Wasano N, Yamashita S, Kusumoto K, et al. Identification of a novel cytotoxic protein, Cry45Aa, from Bacillus thuringiensis A1470 and its selective cytotoxic activity against various mammalian cell lines. J Agric Food Chem. ACS Publications; 2005;53:6313-8.

[7] Cardona LFV, Torres DSR, Salamanca JC. Toxinas de Bacillus thuringiensis con actividad anticancerígena: Parasporinas. Rev Colomb Biotecnol. 2018;20:89-100. 
[8] Nagamatsu Y, Okamura S, Saitou H, Akao T, Mizuki E. Three Cry toxins in two types from Bacillus thuringiensis strain M019 preferentially kill human hepatocyte cancer and uterus cervix cancer cells. Biosci Biotechnol Biochem. Japan Society for Bioscience, Biotechnology, and Agrochemistry; 2010;1001281837.

[9] Espino-Vázquez A, Gómez-Treviño A, Galán-Wong L, Pereyra-Alférez B. Isolation of Bacillus thuringiensis strains with cytotoxic activity against MOLT-4, a leukemia cell line. Microbes Appl Res Curr Adv Challenges. World Scientific; 2012. p. 147-51.

[10] Bravo-D HR, Cruz-Nolasco A, Gutiérrez-Lucas LR, Navarro-Mtz AK. Bioinformatics Analysis of NprRNprX Quorum-Sensing System of Bacillus thuringiensis Isolates from the Papaloapan Region, Oaxaca-Mexico. Adv Biol Chem. Scientific Research Publishing; 2015;5:293.

[11] Espino Vázquez AN. Caracterización biológica de parasporinas en cepas nativas de Bacillus thuringiensis. Universidad Autónoma de Nuevo León; 2014.

[12] WHO. Cancer. World Heal. Organ. 2020.

[13] Harbeck N, Penault-Llorca F, Cortes J, Gnant M, Houssami N, Poortmans P, et al. Breast cancer. Nat Rev Dis Prim [Internet]. 2019;5:66. Recuperado a partir de: https://doi.org/10.1038/s41572-019-0111-2

[14] Nair K, Iskandarani A, Al-Thani R, Mohammad R, Jaoua S. The replacement of five consecutive amino acids in the cyt la protein of Bacillus thuringiensis enhances its cytotoxic activity against lung epithelial cancer cells. Toxins (Basel). Multidisciplinary Digital Publishing Institute; 2018;10:125.

[15] Brasseur K, Auger P, Asselin E, Parent S, Côté J-C, Sirois M. Parasporin-2 from a new Bacillus thuringiensis 4R2 strain induces caspases activation and apoptosis in human cancer cells. PLoS One. Public Library of Science; 2015;10:e0135106.

[16] Alexander MP. A versatile stain for pollen fungi, yeast and bacteria. Stain Technol. Taylor \& Francis; 1980;55:13-8.

[17] Obeidat M. In vitro selective cytotoxicity of activated parasporal proteins produced by Bacillus thuringiensis serovars kumamotoensis and tohokuensis against human cancer cell lines. African J Biotechnol. Academic Journals; 2017;16:2181-8.

[18] Krishnan K, Ker JEA, Mohammed SM, Nadarajah VD. Identification of glyceraldehyde-3-phosphate dehydrogenase (GAPDH) as a binding protein for a $68-\mathrm{kDa}$ Bacillus thuringiensis parasporal protein cytotoxic against leukaemic cells. J Biomed Sci. BioMed Central; 2010;17:86.

[19] Wong RSY, Mohamed SM, Nadarajah VD, Tengku IAT. Characterisation of the binding properties of Bacillus thuringiensis 18 toxin on leukaemic cells. J Exp Clin Cancer Res. BioMed Central; 2010;29:86.

[20] Chubicka T, Girija D, Deepa K, Salini S, Meera N, Raghavamenon AC, et al. A parasporin from Bacillus thuringiensis native to Peninsular India induces apoptosis in cancer cells through intrinsic pathway. J Biosci. Springer; 2018;43:407-16.

[21] Kitada S, Abe Y, Shimada H, Kusaka Y, Matsuo Y, Katayama H, et al. Cytocidal actions of parasporin-2, an anti-tumor crystal toxin from Bacillus thuringiensis. J Biol Chem. ASBMB; 2006;281:26350-60.

[22] Moazamian E, Bahador N, Azarpira N, Rasouli M. Anti-cancer parasporin toxins of new Bacillus thuringiensis against human colon (HCT-116) and blood (CCRF-CEM) cancer cell lines. Curr Microbiol. Springer; 2018;75:1090-8.

[23] Bensaad K, Tsuruta A, Selak MA, Vidal MNC, Nakano K, Bartrons R, et al. TIGAR, a p53-inducible 
regulator of glycolysis and apoptosis. Cell. Elsevier; 2006;126:107-20.

[24] Hecht F, Pessoa CF, Gentile LB, Rosenthal D, Carvalho DP, Fortunato RS. The role of oxidative stress on breast cancer development and therapy. Tumor Biol [Internet]. 2016;37:4281-91. Recuperado a partir de: https://doi.org/10.1007/s13277-016-4873-9

[25] Singh S, Gupta AK. Nitric oxide: role in tumour biology and iNOS/NO-based anticancer therapies. Cancer Chemother Pharmacol [Internet]. 2011;67:1211-24. Recuperado a partir de: https://doi.org/10.1007/s00280011-1654-4

[26] Basudhar D, Miranda KM, Wink DA, Ridnour LA. Advances in breast cancer therapy using Nitric Oxide and Nitroxyl donor agents. Redox-Active Ther. Springer; 2016. p. 377-403.

[27] Kanwar JR, Kanwar RK, Burrow H, Baratchi S. Recent advances on the roles of NO in cancer and chronic inflammatory disorders. Curr Med Chem. Bentham Science Publishers; 2009;16:2373-94.

[28] Rubbo H, Radi R. Antioxidant properties of nitric oxide. Oxidative Stress Dis. MARCEL DEKKER; 2002;8:689-706.

[29] Förstermann U, Sessa WC. Nitric oxide synthases: regulation and function. Eur Heart J. Oxford University Press; 2012;33:829-37.

[30] Kalyanaraman B, Darley-Usmar V, Davies KJA, Dennery PA, Forman HJ, Grisham MB, et al. Measuring reactive oxygen and nitrogen species with fluorescent probes: challenges and limitations. Free Radic Biol Med. Elsevier; 2012;52:1-6.

[31] Tatla S, Woodhead V, Foreman JC, Chain BM. The role of reactive oxygen species in triggering proliferation and IL-2 secretion in T cells. Free Radic Biol Med. Elsevier; 1999;26:14-24.

[32] Baran CP, Zeigler MM, Tridandapani S, Marsh CB. The role of ROS and RNS in regulating life and death of blood monocytes. Curr Pharm Des. Bentham Science Publishers; 2004;10:855-66.

[33] Wierzbicki PM, Adrych K, Kartanowicz D, Dobrowolski S, Stanislawowski M, Chybicki J, et al. Fragile histidine triad (FHIT) gene is overexpressed in colorectal cancer. J Physiol Pharmacol. 2009;60:63-70.

[34] Yu G-R, Qin W-W, Li J-P, Hua W, Meng Y-L, Chen R, et al. HIV-TAT-fused FHIT protein functions as a potential pro-apoptotic molecule in hepatocellular carcinoma cells. Biosci Rep. Portland Press Limited; 2012;32:271-9.

[35] Georgiou CD, Papapostolou I, Grintzalis K. Protocol for the quantitative assessment of DNA concentration and damage (fragmentation and nicks). Nat Protoc. Nature Publishing Group; 2009;4:125.

[36] Duprez L, Wirawan E, Berghe T Vanden, Vandenabeele P. Major cell death pathways at a glance. Microbes Infect. Elsevier; 2009;11:1050-62.

[37] Akiba T, Abe Y, Kitada S, Kusaka Y, Ito A, Ichimatsu T, et al. Crystal structure of the parasporin-2 Bacillus thuringiensis toxin that recognizes cancer cells. J Mol Biol. Elsevier; 2009;386:121-33.

[38] Briggs DC, Naylor CE, Smedley III JG, Lukoyanova N, Robertson S, Moss DS, et al. Structure of the food-poisoning Clostridium perfringens enterotoxin reveals similarity to the aerolysin-like pore-forming toxins. J Mol Biol. Elsevier; 2011;413:138-49.

[39] Diep DB, Nelson KL, Raja SM, Pleshak EN, Buckley JT. Glycosylphosphatidylinositol anchors of membrane glycoproteins are binding determinants for the channel-forming toxin aerolysin. J Biol Chem. ASBMB; 1998;273:2355-60. 
[40] Dragan AI, Casas-Finet JR, Bishop ES, Strouse RJ, Schenerman MA, Geddes CD. Characterization of PicoGreen interaction with dsDNA and the origin of its fluorescence enhancement upon binding. Biophys J. Elsevier; 2010;99:3010-9.

[41] Ohba M, Mizuki E, Uemori A. Parasporin, a new anticancer protein group from Bacillus thuringiensis. Anticancer Res. International Institute of Anticancer Research; 2009;29:427-33.

[42] Abe Y, Shimada H, Kitada S. Raft-targeting and oligomerization of Parasporin-2, a Bacillus thuringiensis crystal protein with anti-tumour activity. J Biochem. Oxford University Press; 2007;143:269-75.

[43] Yamashita S, Katayama H, Saitoh H, Akao T, Park YS, Mizuki E, et al. Typical three-domain Cry proteins of Bacillus thuringiensis strain A1462 exhibit cytocidal activity on limited human cancer cells. J Biochem. Oxford University Press; 2005;138:663-72.

[44] Xu C, Wang B-C, Yu Z, Sun M. Structural insights into Bacillus thuringiensis Cry, Cyt and parasporin toxins. Toxins (Basel). Multidisciplinary Digital Publishing Institute; 2014;6:2732-70.

[45] Ekino K, Okumura S, Ishikawa T, Kitada S, Saitoh H, Akao T, et al. Cloning and characterization of a unique cytotoxic protein parasporin-5 produced by Bacillus thuringiensis A1100 strain. Toxins (Basel). Multidisciplinary Digital Publishing Institute; 2014;6:1882-95.

[46] Laemmli UK. Cleavage of Structural Proteins during the assembly of the head of bacteriophage T4. Nature [Internet]. 1970;227:680-5. Recuperado a partir de: https://doi.org/10.1038/227680a0

[47] Mosmann T. Rapid colorimetric assay for cellular growth and survival: application to proliferation and cytotoxicity assays. J Immunol Methods. Elsevier; 1983;65:55-63.

[48] Brüne B, von Knethen A, Sandau KB. Nitric oxide and its role in apoptosis. Eur J Pharmacol. Elsevier; 1998;351:261-72.

[49] Dhakshinamoorthy S, Porter AG. Nitric oxide-induced transcriptional up-regulation of protective genes by Nrf2 via the antioxidant response element counteracts apoptosis of neuroblastoma cells. J Biol Chem. ASBMB; 2004;279:20096-107.

[50] Choi W-S, Shin P-G, Lee J-H, Kim G-D. The regulatory effect of veratric acid on NO production in LPSstimulated RAW264. 7 macrophage cells. Cell Immunol. Elsevier; 2012;280:164-70.

[51] Noh HJ, Hwang D, Lee ES, Hyun JW, Yi PH, Kim GS, et al. Anti-inflammatory activity of a new cyclic peptide, citrusin XI, isolated from the fruits of Citrus unshiu. J Ethnopharmacol. Elsevier; 2015;163:106-12.

[52] Degli Esposti M. Measuring mitochondrial reactive oxygen species. Methods. Elsevier; 2002;26:335-40.

[53] Halliwell B, Whiteman M. Measuring reactive species and oxidative damage in vivo and in cell culture: how should you do it and what do the results mean? Br J Pharmacol. Wiley Online Library; 2004;142:231-55.

[54] Ha TTN, Huy NT, Murao LA, Lan NTP, Thuy TT, Tuan HM, et al. Elevated levels of cell-free circulating DNA in patients with acute dengue virus infection. PLoS One. Public Library of Science; 2011;6:e25969.

[55] Riccardi C, Nicoletti I. Analysis of apoptosis by propidium iodide staining and flow cytometry. Nat Protoc [Internet]. 2006;1:1458-61. Recuperado a partir de: https://doi.org/10.1038/nprot.2006.238

Acknowledgements. KC-A acknowledges the scholarship granted by CONACyT (No. 615647). DBB and AC-N acknowledges the scholarship granted by CONACyT (CB-2015/258587). 
Contributions. AKN-M, MAP-R conceived and designed the research. DBB wrote the manuscript. KC-A, AC-N, DBB and CL conducted the experiments. MAP-R, MASRM, SRCV, SBL, P-PL, CL and AKN-M analyzed the obtained data. All authors read and approved the manuscript.

Funding information. This study was funded by CONACyT (CB-2015/258587); Sagrillo Rorato, M. thanks UFSM, UFN and FAPERGS (ARD 17/2551-0000805-7); Santos, R.C.V thanks FAPERGS (PqG 17/25510001) and CNPq (Pq 310360/2019-6).

Competing interests. The authors declare no competing interests. 


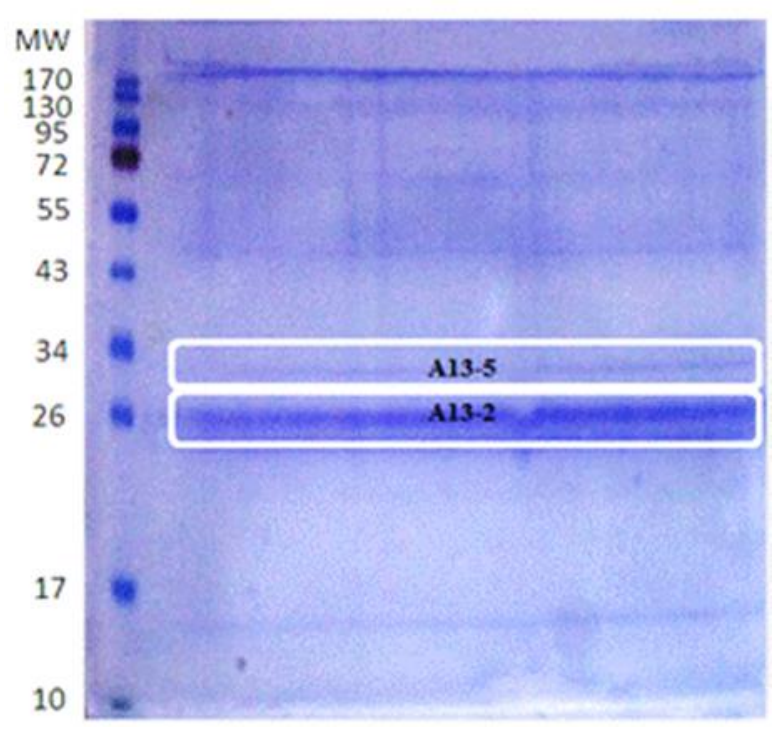

Figure 1. SDS-PAGE profile of parasporal inclusion proteins of B. thuringiensis isolate of A13 strain. Line 1, molecular weight marker, lane 2 solubilized parasporal inclusions of the isolate A13 strain.

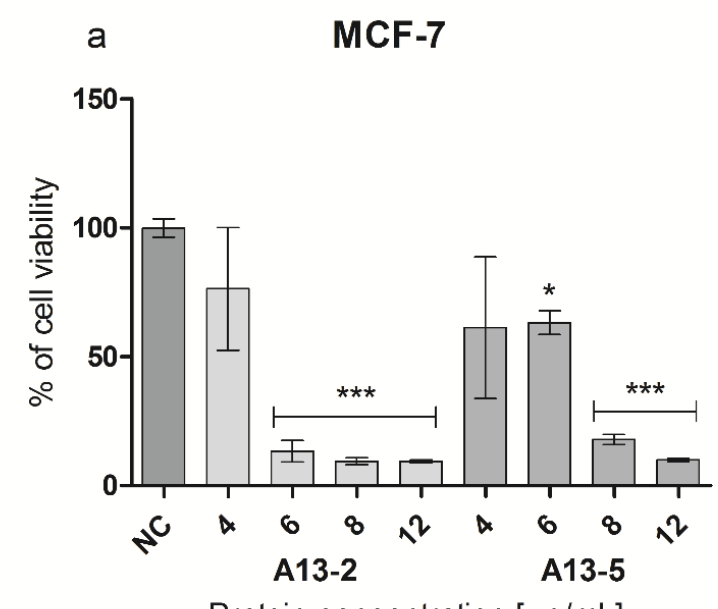

Protein concentration $[\mu \mathrm{g} / \mathrm{mL}]$

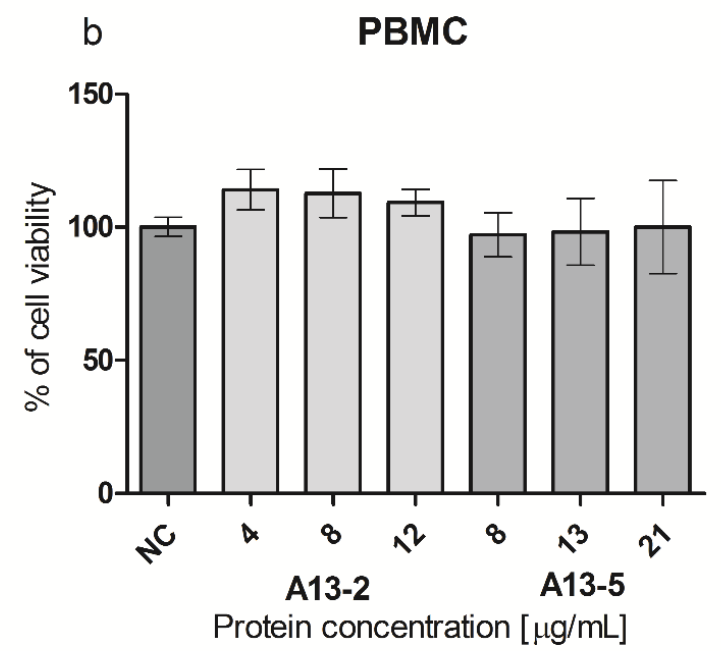

Protein concentration $[\mu \mathrm{g} / \mathrm{mL}]$

Figure 2. Cytotoxicity of B. thuringiensis parasporal inclusions against MCF-7at 48hours and normal cells (PBMC) at 48 hours of incubation. Results are expressed in percentage of negative control (NC). The data are mean \pm standard deviation $(\mathrm{SD}) . * \mathrm{P}<0.05$ were considered statistically significant. 

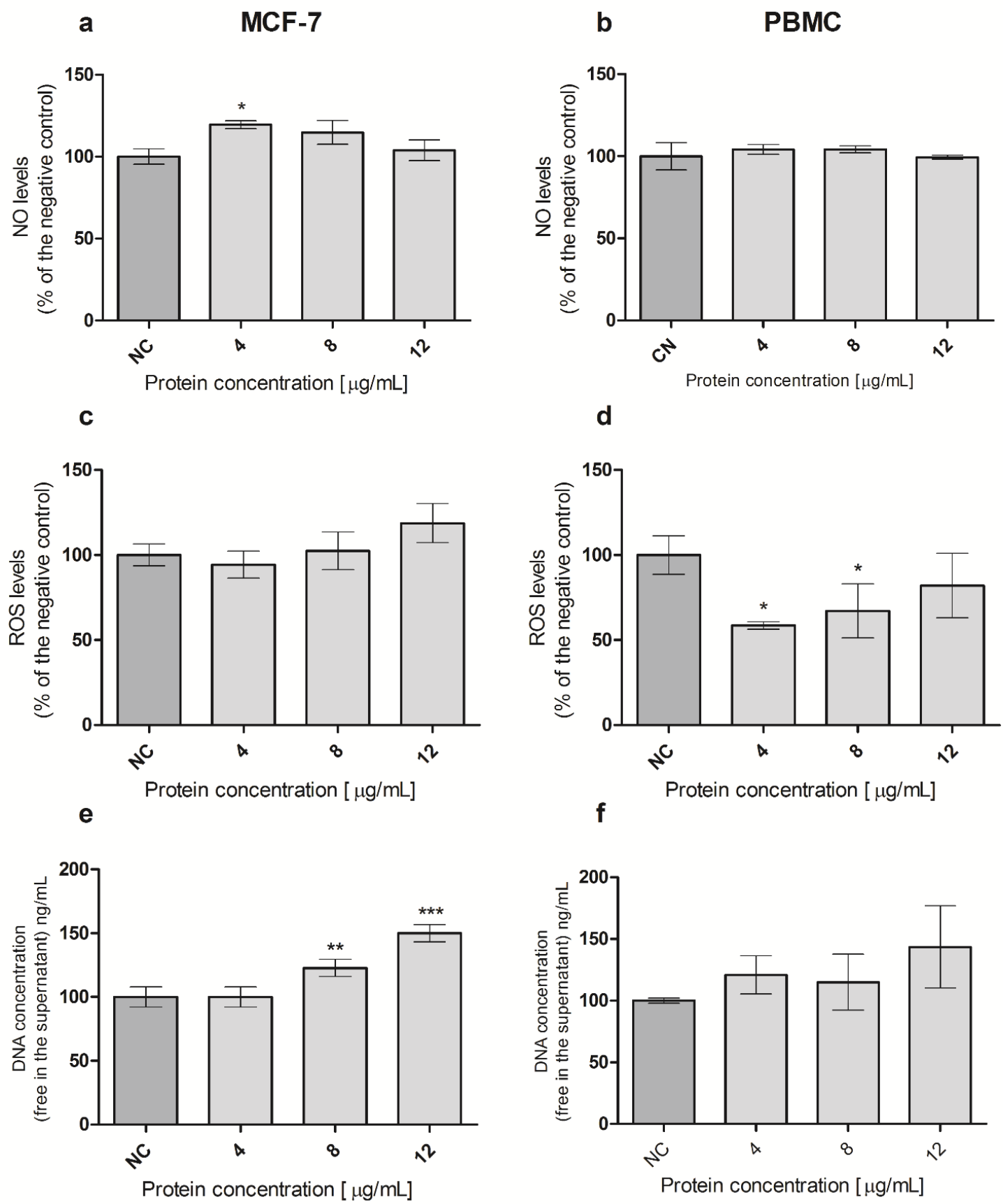

Figure 3. Oxidative stress role after treatment with B. thuringiensis parasporal protein A13-2 against MCF-7 cells at 72 hours and normal cells (PBMC) at 48 hours of incubation. Nitric oxide levels in MCF-7 (a) and PBMC (b). ROS levels in MCF-7 (c) and PBMC (d). Determination of DNA fragmentation in MCF-7 (e) and PBMC (f). Results expressed in percentage of negative control (NC). The data are mean \pm SD. $* P<0.05$ were considered statistically significant. 

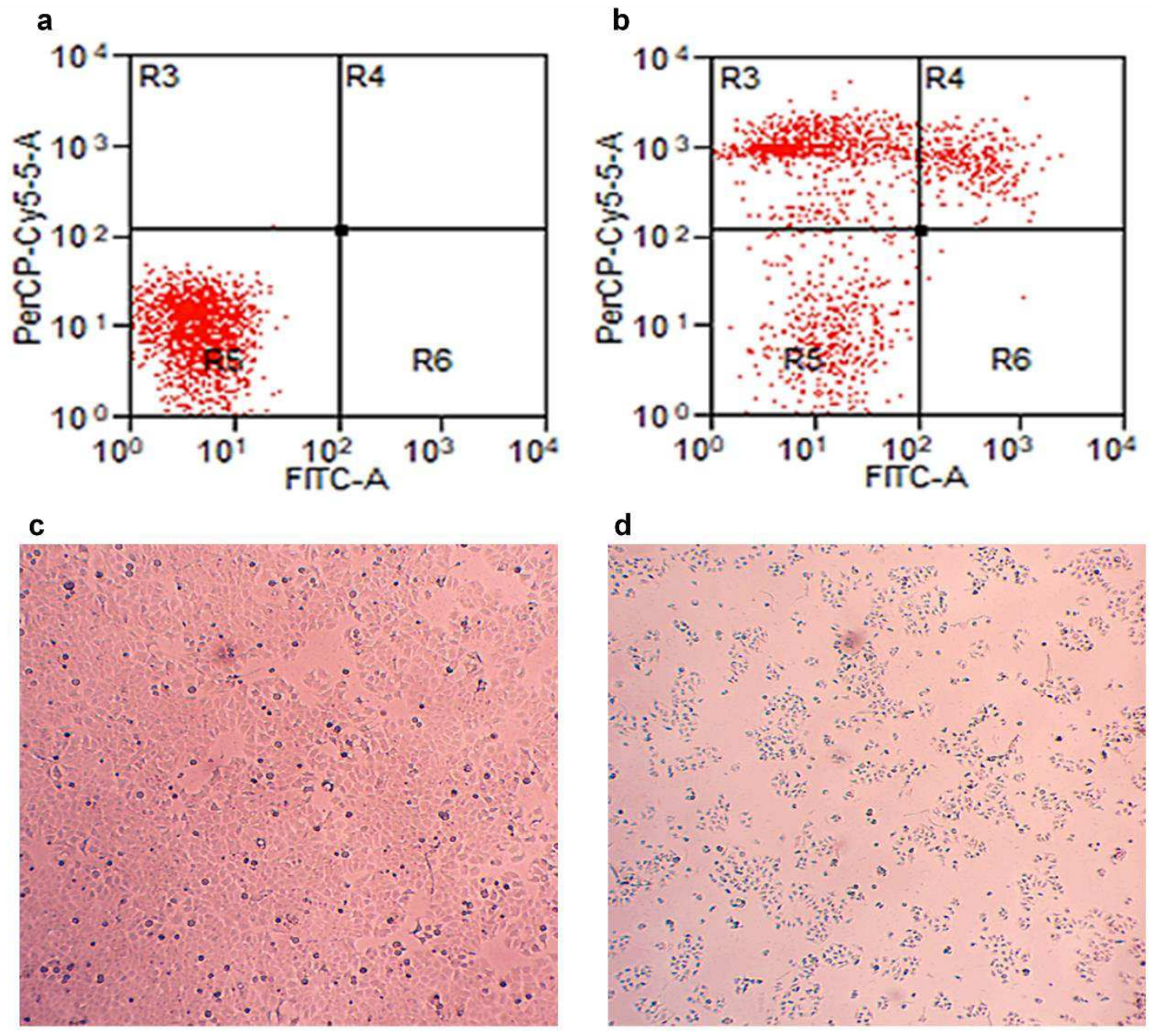

e

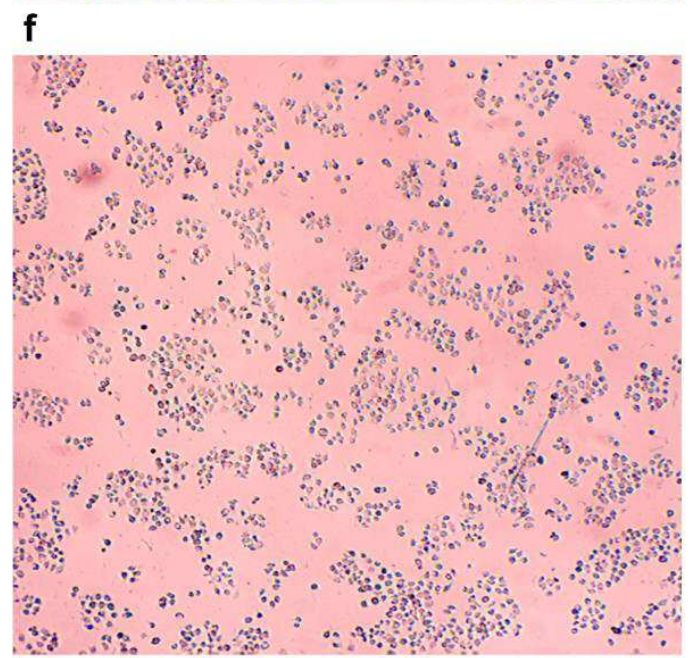

Figure 4. Apoptosis and necrosis determination and cytopathic effect of treatment with A13-2 protein to 24 hours of incubation on MCF-7 cells. Negative control cells (a); Annexin V-PI flow cytometry where the R3 expresses necrotic cells, R4 late apoptotic cells, R5 viable cells and R6 early apoptotic cells after A13-2 
protein $5 \mu \mathrm{g} / \mathrm{mL}$ (b). Cytopathic effect of protein of B. thuringiensis A13-2 on MCF-7, Negative control (c), Doxorubicin as positive control (d), A13-2 $4 \mu \mathrm{g} / \mathrm{mL}$ (e) and A13-2 $8 \mu \mathrm{g} / \mathrm{mL}$ (f). The inverted microscopic observations were done at 48 hours post-inoculation. 


\section{Figures}

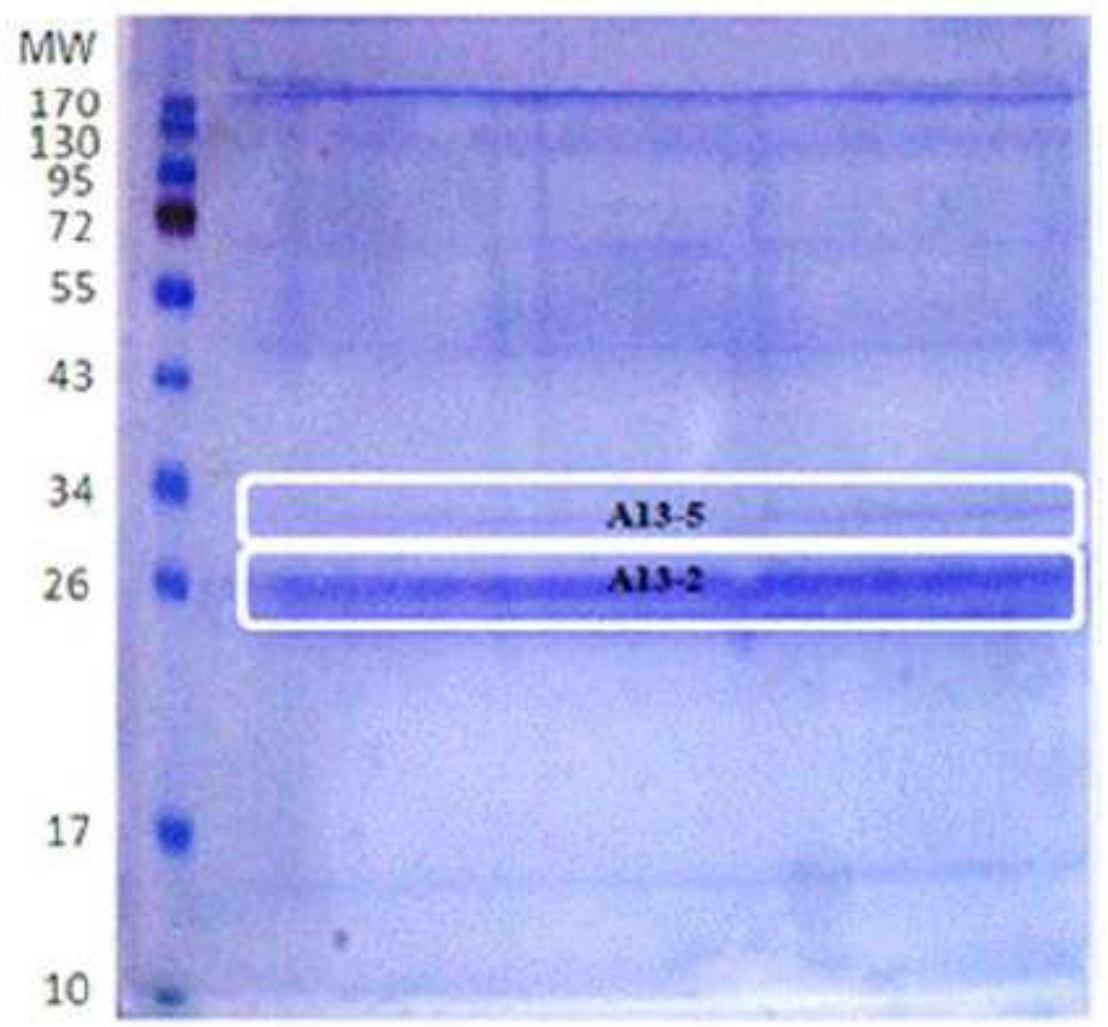

Figure 1

SDS-PAGE profile of parasporal inclusion proteins of B. thuringiensis isolate of A13 strain. Line 1, molecular weight marker, lane 2 solubilized parasporal inclusions of the isolate A13 strain.
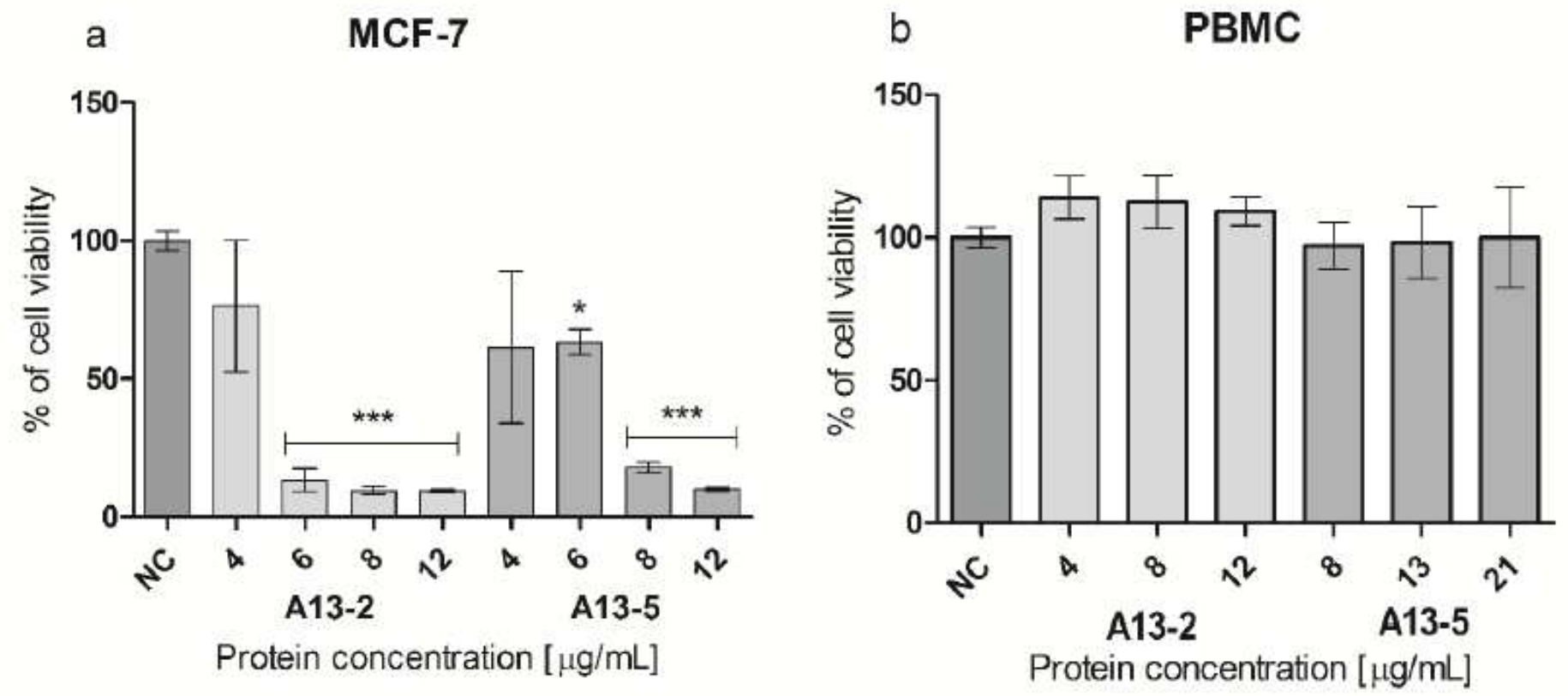
Figure 2

Cytotoxicity of B. thuringiensis parasporal inclusions against MCF-7at 48hours and normal cells (PBMC) at 48 hours of incubation. Results are expressed in percentage of negative control (NC). The data are mean \pm standard deviation (SD). ${ }^{*}<0.05$ were considered statistically significant.
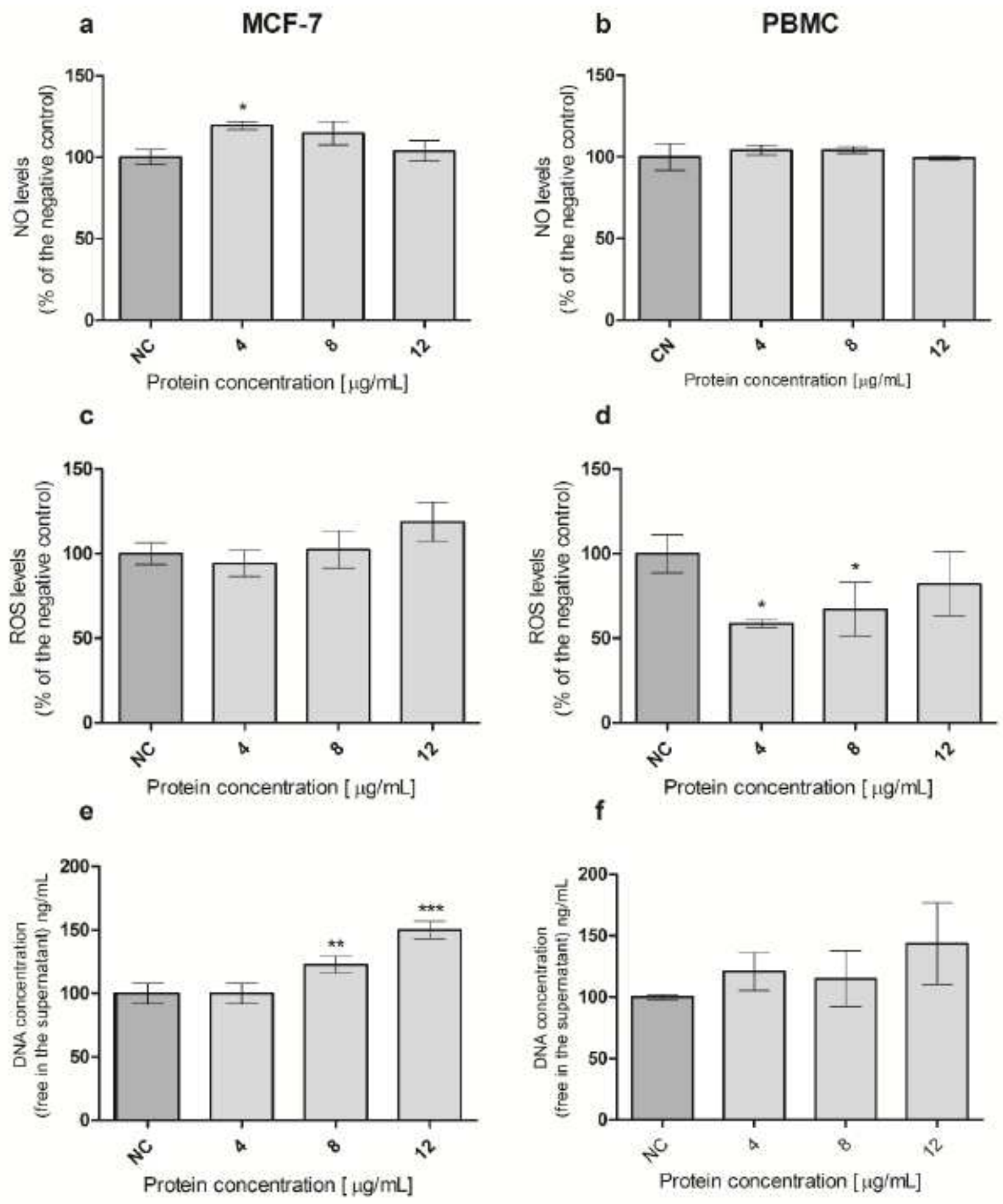

Figure 3 
Oxidative stress role after treatment with $B$. thuringiensis parasporal protein A13-2 against MCF-7 cells at 72 hours and normal cells (PBMC) at 48 hours of incubation. Nitric oxide levels in MCF-7 (a) and PBMC (b). ROS levels in MCF-7 (c) and PBMC (d). Determination of DNA fragmentation in MCF-7 (e) and PBMC (f). Results expressed in percentage of negative control (NC). The data are mean $\pm S D$. ${ }^{*} P<0.05$ were considered statistically significant.
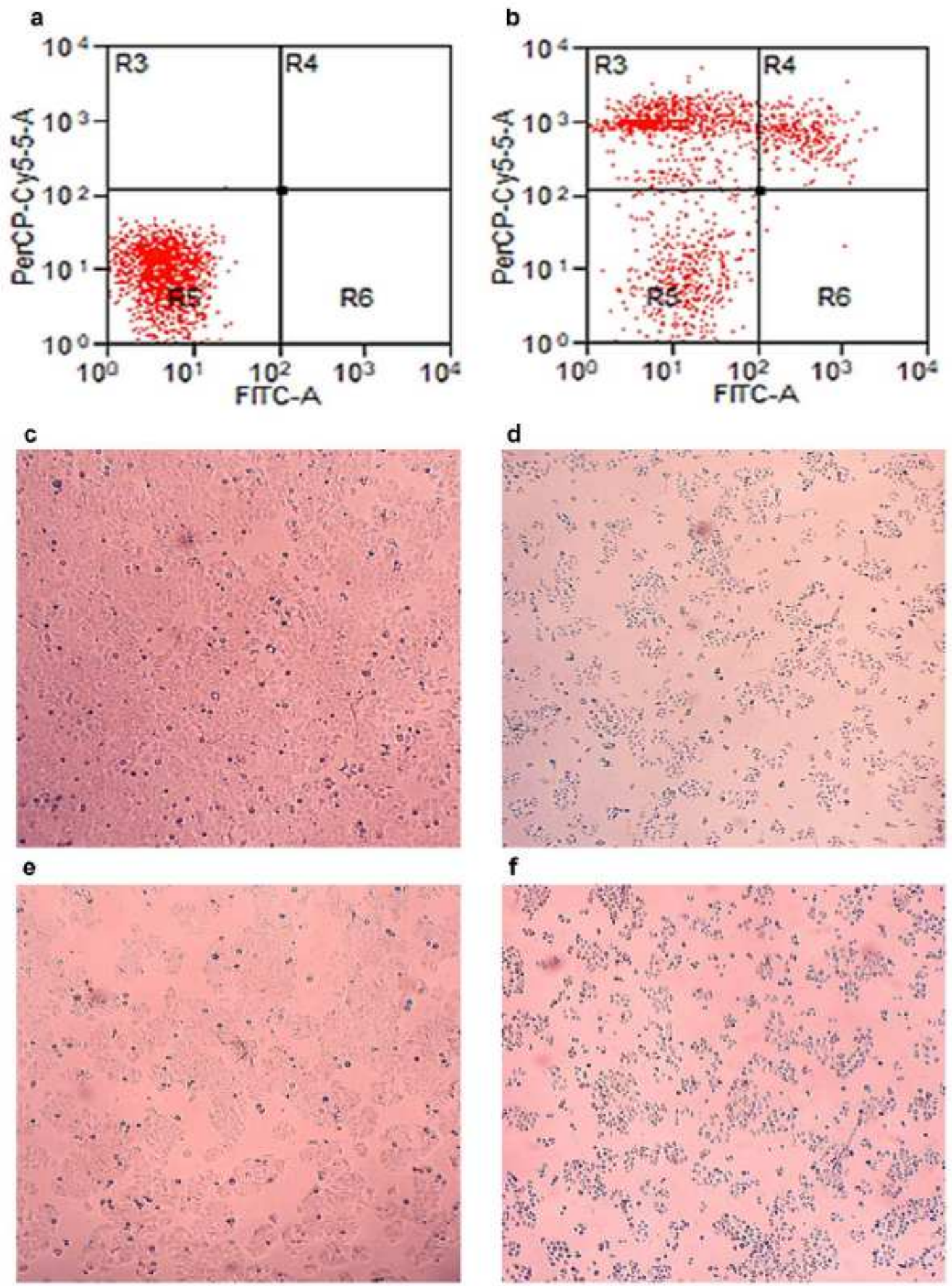
Apoptosis and necrosis determination and cytopathic effect of treatment with A13-2 protein to 24 hours of incubation on MCF-7 cells. Negative control cells (a); Annexin V-PI flow cytometry where the R3 expresses necrotic cells, R4 late apoptotic cells, R5 viable cells and R6 early apoptotic cells after A13-2 protein $5 \mu \mathrm{g} / \mathrm{mL}$ (b). Cytopathic effect of protein of B. thuringiensis A13-2 on MCF-7, Negative control (c), Doxorubicin as positive control (d), A13-2 $4 \mu \mathrm{g} / \mathrm{mL}$ (e) and A13-2 $8 \mu \mathrm{g} / \mathrm{mL}$ (f). The inverted microscopic observations were done at 48 hours post-inoculation. 